\section{5. 良性脳腫瘍手術における穿通枝温存の工夫}

名古屋大学大学院医学系研究科脳神経外科

齋藤 清, 永谷 哲也，相見 有理，伊藤 英治， 吉田＼cjkstart純

良性脳腫瘍で穿通枝が問題となるのは，主に鞍上部および 傍鞍部腫瘍である，穿通枝の障害では，麻痺，記銘力障害， 視力障害など重大な後遺症の可能性が高い. したがって，手 術に際しては第一に「穿通枝を必ず温存する」という確固た る意識が不可欠である。鞍上部・傍鞍部の良性腫瘍のうち, 問題となることの多い髄膜腫および頭蓋咽頭腫を中心に解説 する．１腫瘍の進展方向と穿通枝の圧迫された方向，走行を 予測する。（2)クモ膜に注意して穿通枝の走行を同定する。 (3) 腫瘍は進展を戻す方向に虽離する。(4)腫瘍に適度な牽引を加 えると剝離が容易になる。杉田のシステムを正しく用いれば， 脳は安全に retract でき, 腫陽に熊手リトラクターで適度な牽 引を加えることができる。（5)腫瘍表面に癒着した穿通枝は， できればクモ膜とともに剝離する。⑥クモ膜面がみつからな い時には，動脈本幹の穿通枝のない面（前面または下面）を 剝離して本幹の走行を確認し, 親血管と穿通枝周囲に腫煬を 残して，安全な部分をまず摘出する。(7)凝固を避け，術中乾 燥させないように注意する。

\section{6. 神経膠腫摘出術における穿通枝温存}

東北大学大学院神経外科学分野 1

東北大学量子診断学分野 2

隈部 俊宏 ${ }^{1}$, 中川 敦寛 ${ }^{1}$, 冨永 悌二 ${ }^{1}$, 高橋 昭喜 $^{2}$

神経膠腫摘出術においてはいずれの部位においても，摘出 領域を通過する動静脈の温存処置を必要とする，皮質動脈レ ベルの管径の動脈は, 腫瘍への分枝を一本ずつ丁寧に凝固切 断することにより遊離温存することが可能である。しかし管 径が穿通枝レベルの動脈を腫瘍血管と鑑別して温存するのは 技術的にまだ難しいことと，立体的な腫瘍摘出工程のどの段 階・位置でその血管が露出するのかを術中に把握するのが難 しいことが問題点として挙げられる，島弁蓋部神経膠腫摘出 術では，まさにこの問題に直面することになる．温存上問題 となる動脈は, (1)外側線条体動脈 (LSA), (2)long insular artery, (3)弁蓋部（M3）および終末部（M4）からの髄質動脈 (medullary artery) である。これらの障害は，直接錐体路症 状を生ずる，さらに言語優位半球では，言語機能温存下に血 管温存处置を行う必要があるが，これらの問題を回避するた めの方法は確立されていない，現状までで可能となった項目 と問題点をまとめるとともに, 将来の展望を報告したい.

\section{Preservation of Perforators in Neuroendovascu- lar Treatment}

Ceutre Hospitalier de Bicêtre

Pierre Lasjaunias M. D., Ph. D.

Five examples can be used to demonstrate the interference of perforators in endovascular management. The "leit motiv" of each of these examples will be the mastership of the anatomic variations :

Vertebro-basilary dissections will allow depending on the origin of PICA to predict the role played by the various segments of the intra dural vertebral artery as well as the origin of the anterior spinal artery. Sacrifice of the parent vessel will not be either associated with medullar infarction.

Spinal cord AVM supplied by the anterior spinal artery will allow as well selective injection and embolization with the potential risk of Brown Sequard syndrome. The differenciation between perforators and pial branches of the anterior spinal artery should be made prior to take the decision of embolization. Following such rules, the safety can be maximum unless reflux in the axis vertebral artery is noted.

In vein of Galen arteriovenous malformation, sub-ependymal supply to the choroid fissure is often noted. These branches should not be confused with trans-mesencephalic arteries. The former can be easily catheterized distally to allow complete safe embolization of the vein of Galen without damage for the brain stem.

Anterior choroïdal supplied brain AVM requires superselective injection and high quality angiography including 3D pictures each time possible. Provided such precautions, embolization of the anterior choroïdal artery will be safe unless retrograde thrombosis occurs in the main trunk.

Basilar tip aneurysm, nearly always occur in either symmetrical or asymmetrical caudal fusion of the basilar tip. This basilar tip fusion allows prediction of the origin of the main perforators to the mamillary-hypothalamic region. Preservation of the prominent P1 segment to the supply of the region can be anticipated and therefore preserved.

Conclusion : The best way of preserving the perforators during neuroendovascular treatment is perfect knowledge of anatomy to avoid gessing or manipulation of unnecessary anticoagulation or complex hazardous parent vessel permeation. Picturing the perforators is not the goal, demonstrating them is most of the time not necessary if one knows where to expect the most dangerous ones. 